УДК $347: 78 ; 532 / 8$

DOI https://doi.org/10.32849/2663-5313/2020.11.30

\title{
Андрій Ірклієнко,
}

аспірант

Інституту законодавства Верховної Ради України

\section{КОНСТИТУЦИЙНО-ПРАВОВИЙ СТАТУС ДВОПАЛАТНОГО ПАРЛАМЕНТУ ФЕДЕРАТИВНОЇ РЕСПУБЛІКИ НІМЕЧЧИНА}

У статті здійснено аналіз конституційно-правового статусу Парламенту Федеративної Республіки Німеччина. Резюмовано, що Німеччина є класичною парламентською республікою. З'ясовано, що в парламентській республіці застосовується дещо інший принцип поділу влади. Для президентської республіки характерний поділ влади на виконавчу (на чолі з президентом), законодавчу і судову, в парламентській республічі влада ділиться на партійну (правляча партія і опозищія), адміністративну та судову.

Німеччина має федеральний устрій. Таким чином, політична система держави діліться на два рівні: федеральний, на якому приймаються загальнодержавні рішення міжнародного значення, і регіональний, на якому вирішуються завдання федеральних земель. Кожен рівень має власні органи виконавчої, законодавчої і судової влади. Німецький Бундестаг (парламент) і Бундесрат (орган представниитва земель) здійснюють законодорадчу і законодавчу функиї на федеральному рівні й уповноважені більшістю голосів, у дві третини в кожному з органів, вносити зміни до конституиії. На регіональному рівні законотворчість здійснюється парламентами земель - ландтагами і бюргершафтами (парламенти міст-земель Гамбург і Бремен). Вони ухвалюють закони, що діють у межах земель. Виконавча влада на федеральному рівні представлена Федеральним урядом, на чолі якого стоїть бундесканилер. Главою органів виконавчої влади на рівні суб'єктів федерачії є прем'єр-міністр. Федеральною і земельними адміністрачіями керують міністри, які очолюють адміністративні органи.

На перший погляд, парламентська система ФРН є типовою для федеративного устрою держави i складається з двох палат - нижньої (Бундестагу) $і$ верхньої (Бундесрату). Члени Бундесрату не обираються безпосередньо народом, а є членами урядів земель, які їх призначають і відкликають. Сучасний Бундесрат - ие так званий «конгрес урядів». При ивому илени Бундесрату повинні слідувати вказівкам, які отримані ними від своїх регіональних урядів, тобто не мають критерію свободи здійснення депутатських повноважень, характерних для всіх членів законодавчого органу.

Специффінню рисою німецького конституиійного права є особлива система виборів, що застосовується для обрання членів Бундестагу. 3 огляду на федеративну модель державного устрою в Німеччини діє спечифічна виборча система. Німецький виборець на виборах у Бундестаг має два голоси. Свій «периий голос» (нім. Erststimте) громадянин віддає за депутата у своєму одномандатному окрузі, який буде представляти одну із 16 федеральних земель (свій регіон) у Бундестазі. «Другий голос» (нім. Zweitstimте) призначений для голосування за партійний список, від чого далі залежсть партійна структура парламенту, а також і те, яка саме фракція або партійна коалічія матиме більшість для обрання бундесканилера.

Ключові слова: парламентаризм, особливості, республіка, законодавча влада, вибори.

Постановка проблеми. Федеративна Республіка Німеччина (ФРН) за формою правління - парламентська республіка. Такий конституційний лад, на відміну від інших, акцентує увагу на ролі парламенту в системі органів державної влади. Основний Закон Німеччини закріпив п'ять постійно діючих конституційних органів: Федеральний президент, Федеральний уряд (виконавчі), Бундесрат, Бундестаг (законодавчі), Федеральний конституційний суд (судові).

Сьогодні Німеччина $є$ класичною парламентською республікою. У парламентській республіці застосовується дещо інший принцип поділу влади. Для президентської республіки характерний поділ влади на виконавчу (на чолі з президентом), законодавчу i судову, то в парламентській республіці влада ділиться на партійну (правляча партія і опозиція), адміністративну та судову.

Німеччина має федеральний устрій. Таким чином, політична система держави діліться на два рівні: федеральний, на якому приймаються загальнодержавні рішення міжнародного значення, й регіональний, на якому вирішуються завдання федераль- 
них земель. Кожен рівень має власні органи виконавчої, законодавчої і судової влади. Німецький Бундестаг (парламент) i Бундесрат (орган представництва земель) здійснюють законодорадчу і законодавчу функції на федеральному рівні й уповноважені більшістю голосів, у дві третини в кожному з органів, вносити зміни до конституції. На регіональному рівні законотворчість здійснюється парламентами земель - ландтагами і бюргершафтами (парламенти міст-земель Гамбург і Бремен). Вони ухвалюють закони, що діють у межах земель. Виконавча влада на федеральному рівні представлена Федеральним урядом, на чолі якого стоїть бундесканцлер. Главою органів виконавчої влади на рівні суб'єктів федерації є прем'єр-міністр. Федеральною і земельними адміністраціями керують міністри, які очолюють адміністративні органи.

Мета статті. На перший погляд, парламентська система ФРН є типовою для федеративного устрою держави і складається $з$ двох палат - нижньої (Бундестагу) і верхньої (Бундесрату). Однак нині науковці наполягають на виокремленні особливостей контитуційно-правового статусу двопалатного парламенту ФРН. Зокрема, проблемі тлумачення функцій, структури, змісту парламентаризму ФРН досліджували А. Свгеньєва [2], С. Шюттемаєр [6], М. Цахло [7], Л. Прокопенко [5], I. Нагребецька [4], Ю. Гартманн [1], О. Зайчук [3] та ін. Водночас нині відсутні цілеспрямовані наукові дослідження проблеми конституційно-правового статусу Парламенту Федеративної Республіки Німеччина, що вважаємо метою нашої статті.

Виклад основного матеріалу. За змістом Основного закону і відповідно до теоретичних концепцій вчених ФРН, парламент у країні є однопалатним. Цією палатою вважають Бундестаг, який здійснює законодавчу та іншу діяльність. Бундестаг є парламентом Федеративної Республіки Німеччини. Рішення, які він ухвалює, $\epsilon$ народними рішеннями. Бундесрат, за посередництвом якого суб'єкти федерації беруть участь у законодавстві й управлінні країною, є, на думку ряду німецьких учених-теоретиків, органом «верховної бюрократії земель», що не розглядається ні в Основному Законі, ні в наукових роботах як друга палата парламенту. Однак інша когорта науковців, причому не без вагомих підстав, уважають, що парламент у ФРН складається із двох палат - Бундестагу (верхня) і Бундесрату (нижня), які не мають рівного статусу. Остання обставина знаходить своє вираження в порядку форму- вання палат, термінах повноважень, обсягу повноважень. Ми дотримуватимемось позиції останніх. Парламент Федеративної Республіки Німеччина фактично складається 3 двох палат: нижньої - Бундестагу і верхньої - Бундесрату (формально в Німеччині деякими юристами Бундесрат не розглядається як палата Парламенту).

Бундесрат прийнято також характеризувати як сполучну ланку між Федерацією і землями, одним із ключових завдань якого $€$ урівноваження інтересів - відповідно Федерації і земель. Ця функція Бундесрату випливає з того, що, будучи федеральним органом, він формується землями - відповідний порядок формування і компетенція Бундесрату покликані певною мірою компенсувати землям втрату значної частини законодавчих компетенцій. Крім того, будучи законодавчим органом, Бундесрат формується виконавчою владою земель, що дозволяє забезпечити безпосереднє використання досвіду виконання законодавства в законотворчому процесі.

Бундесрат нерідко називають «найоригінальнішим внеском» Німеччини в рішення проблем федералізму. За своєю структурою, завданнями та організацією діяльності він насправді помітно відрізняється від своїх побратимів - вищих палат парламентів інших країн, зокрема й з федеративним устроєм. 3 урахуванням особливостей формування Бундесрату і його повноважень у німецькій політичній і правовій літературі періодично ставиться під сумнів його статус як другої, або вищої, палати німецького парламенту.

Водночас необхідно підкреслити, що фактично Бундесрат відіграє надзвичайно важливу роль у законодавчому процесі - не тільки консультативну, а й вирішальну (нижче цю роль буде детально описано). Якщо вважати визначальним критерієм для віднесення органу до числа законодавчих не порядок формування i формально певний (нехай i в Основному законі) статус, а його роль у прийнятті законодавчих актів, то можна з упевненістю говорити, що Бундесрат є частиною німецького парламенту. Однак його специфіка - як у порівнянні з Бундестагом, так і в порівнянні з вищими палатами двопалатних парламентів інших країн - настільки очевидна, що політологи та юристи-конституціоналісти називають Бундесрат єдиним у своєму роді органом у світі.

У Бундесрат входять представники земельних урядів. Саме уряди земель призначають і відкликають своїх представників у Бундесраті. Відповідно, ніяких виборів у Бундесрат не проводиться. Періодичні зміни в його складі пов’язані з результатами 
виборів у відповідних федеральних землях (тут обираються земельні парламенти, які формують уряди земель, а останні у свою чергу визначають своїх представників у Бундесраті). При цьому членами Бундесрату можуть бути тільки діючі члени урядів відповідних земель. Залежно від чисельності населення земля має від трьох до шести голосів. Землі, які мають менше 2 млн жителів, володіють трьома голосами, від 2 до 6 млн - 4 голосами, 6-7 млн - 5 голосами і понад 7 млн жителів - 6 голосами. Таким чином, натепер землі мають у сукупності 69 голосів. Описаний розподіл голосів можна охарактеризувати як результат компромісу між принципами федеративного і демократичного представництва.

Члени Бундесрату не обираються безпосередньо народом, а є членами урядів земель, які їх призначають і відкликають. Сучасний Бундесрат є так званим «конгресом урядів». При цьому члени Бундесрату повинні виконувати вказівки, які отримані ними від своїх регіональних урядів, тобто не мають критерію свободи здійснення депутатських повноважень, характерних для всіх членів законодавчого органу.

Специфічною рисою німецького конституційного права є особлива система виборів, що застосовується для обрання членів Бундестагу. 3 огляду на федеративну модель державного устрою Німеччини діє специфічна виборча система. Німецький виборець на виборах у Бундестаг має два голоси. Свій «перший голос» (нім. Erststimme) громадянин віддає за депутата у своєму одномандатному окрузі, який буде представляти одну із 16-ти федеральних земель (свій регіон) у Бундестазі. «Другий голос» (нім. Zweitstimme) призначений для голосування за партійний список, від чого далі залежить партійна структура парламенту а також і те, яка саме фракція або партійна коаліція матиме більшість для обрання бундесканцлера.

При цьому якщо кандидат виграв округ (отримав більшість «перших голосів» в окрузі), він стає депутатом незалежно від того, яке місце він посів у підсумковому партійному списку. Більш того, навіть якщо вказаний партійний список не подолав 5\% виборчий бар'єр, депутат все одно вважається обраним, якщо отримав більшість «перших голосів» в окрузі.

Така ситуація регулярно призводить до того, що великі партії отримують більше прямих мандатів («перших голосів»), ніж кількість мандатів, на які вони мають право претендувати в результаті виборів за партійними списками («другим голосам»). Для врегулювання цієї проблеми німецькою виборчою системою передбачені так звані «зрівнялівські мандати», які компенсуються іншим партіям для досягнення виборчого паритету. Зазначені норми призводять до того, що чисельність Бундестагу не фіксована і залежить від різниці в «перших» i «других» голосах.

Незважаючи на те, що зазначена система здається змішаною, насправді вона є варіантом пропорційної системи 3 відкритими списками, оскільки підсумковий політичний розклад у Бундестазі повністю залежить від «других голосів», тоді як перші «мажоритарні» голоси служать виключно для можливості жителя округу вибрати свого депутата, «прив'язаного» до їхнього округу. Бундесрат не має терміну обрання, його склад частково змінюється, коли в одній (або кількох) із федеральних земель відбувається зміна Уряду. Як орган законодавчої влади Бундесрат може схвалювати або не затверджувати такі федеральні закони, визначати регламент своєї роботи, формувати власні комісії. Крім того, оголошення стану оборонної війни вимагає обов'язкового схвалення Бундесрату.

\section{Висновки}

Парламент Федеративної Республіки Німеччина фактично складається із двох палат: нижньої - Бундестаг і верхньої - Бундесрат (формально в Німеччині деякими юристами Бундесрат не розглядається як палата Парламенту). До повноважень Бундестагу відносяться: законотворчість, право на внутрішню організацію $\mathrm{i}$ контрольна функція. В області законотворчості Бундестаг відіграє основну роль. Бундесрат також має повноваження в законодавчому процесі, проте є закони, які не вимагають схвалення з боку Бундесрату. Верхня палата насамперед розглядає закони, які зачіпають інтереси й потреби земель. Право законодавчої ініціативи має Бундесрат і Федеральний уряд. Бундесрат не має певного терміну повноважень, він також не може бути розпущений. Його склад змінюється в залежності від виборів в ландтаги земель. Партійний склад не має значення, фракції не утворюються, проте групи членів Бундесрату від земель з однієї і тієї ж партією блокуються між собою. Голоси землі можуть подаватися тільки узгоджено, єдиним списком.

Бундесрат приймає свій регламент. Натепер діє регламент 1966 року в редакції 1988 року, в якому регламентовані загальні положення (про членів Бундесрату, легіслатурі тощо), про утворення і правове становище органів Бундесрату (президія, комітети, секретаріат тощо), про засідання Бундесрату 
(підготовка, скликання, керівництво, кворум тощо), про виробництво в комітетах, про провадження у справах Європейського Союзу. Бундесрат обирає голови терміном на 1 рік, він скликує засідання, визначає порядок денний, керує дебатами, вирішує питання про проведення голосування. Голова має адміністративну владу в будівлі Бундесрату. Він заміщає Федерального президента, якщо той тимчасово не може виконувати свої функції.

\section{Список використаних джерел:}

1. Гартманн Ю. Держава, право, громадяни за умов демократії. URL: http://www.tatsachenueber-deutschland.de/uk/

2. Євгеньєва А. Німецьке «серце демокраTiï». URL: http://www.parlament.org.ua/index. php?action $=$ magazine $\&$ id $=9 \&$ ar $\_i d=98 \&$ iar id $=21 \&$ as $=2$

3. Зайчук О.В., Оніщенко Н.М. Теорія держави і права. Академічний курс : підручник. Київ : Юрінком Інтер, 2006. URL: http://ebk.net.ua/ Book/law/zaychuk tdp/part3/2710.htm

4. Нагребецька I. Політика реформи чи реформа без політики? URL: http://dialogs.org.ua/ issue full.php?m_id=7300

5. Прокопенко Л.Л., Шабатіна І.А. Публічна служба в країнах ЄC. URL: http://www.nbuv.gov.ua/ e journals/Patp/2009-01/ProkopenkoStat.pdf

6. Сюзанна С. Шюттемаєр. Німецький варіант інституціалізації парламенту. URL: http:// www.rada.gov.ua/LIBRARY/catalog/analit/ deu011.txt 24. Режим доступу : http://www.news2

7. Цахло М. Судова система ФPH. URL http://www.justinian.com.ua/article.php?id=1440

Andrii Irkliienko. Constitutional and legal status of two-chamber parliament of the Federal Republic of Germany

The article analyzes the constitutional and legal status of the Parliament of the Federal Republic of Germany. It has been summarized that Germany is a classical parliamentary republic. It has been discovered that a slightly different principle of division of powers is applied in a parliamentary republic. It is characteristic though for a presidential republic to divide the powers into executive (headed by the president), legislative and judicial, while in a parliamentary republic system, the powers are divided into partisan (ruling party and opposition), administrative and judicial.

Germany has a federal system. Thus, the political system of the state is divided into two levels: the federal, at which national decisions of international importance are made, and the regional, at which the issues of the federal lands are settled. Each level has its own executive, legislative and judicial bodies. The German Bundestag (the Parliament) and the Bundesrat (the body that represents Lands) conduct law advisory and legislative functions at the federal level and are authorized by the majority of two-thirds of votes in each of the bodies to amend the Constitution. At the regional level, lawmaking is committed by the parliaments of the lands - Landtags and Burgerschafts (parliaments of the city-states of Hamburg and Bremen). They pass the laws that operate within the lands. The executive power at the federal level is represented by the Federal Government, which is headed by the Chancellor. The head of the executive bodies at the level of the subjects of the federation is the Prime Minister. The Federal and Land administrations are run by ministers who head the administrative bodies.

At the first sight, the parliamentary system of the Federal Republic of Germany is typical for the federal structure of a state and consists of two chambers - the lower (Bundestag) and upper (Bundesrat). The members of the Bundesrat are not directly elected by the people, but are members of the governments of the lands that appoint and withdraw them. The modern Bundesrat is the so-called "congress of governments". At the same time, members of the Bundesrat must follow the instructions they have received from their regional governments, namely they do not have the criterion of freedom to carry out parliamentary powers, which is characteristic for all members of the legislative body.

A specific feature of German constitutional law is the special system of elections used to elect members of the Bundestag. Given the federal model of a state form of the government in Germany, there is a specific electoral system. A German voter has two votes in the Bundestag elections. The citizen gives their "first vote" (German: Erststimme) for a deputy in their single-seat constituency, who will represent one of the 16 federal lands (their region) in the Bundestag. The "second vote" (German: Zweitstimme) is intended for the use to vote for the party list, on which the party structure of the parliament will depend in the future, as well as which parliamentary group or party coalition will have the majority to elect the chancellor.

Key words: parliamentarism, peculiarities, republic, legislative power, elections. 